\title{
Komunikasi Antarpribadi Dokter Dengan Pasien dalam Membantu Penyembuhan Pasien di Klinik Cendana
}

\author{
Tommy Dwi Panitra, H.H Daniel Tamburian \\ tommy.915150027@stu.untar.ac.id, danielt@fikom.untar.ac.id
}

Fakultas Ilmu Komunikasi Universitas Tarumanagara

\begin{abstract}
This study attempts to examine the role of communication antarpribadi fought between the doctor with patients at the clinic sandalwood. The theory used in this research was communication theory, interpersonal communication, the effectiveness of interpersonal communication, barrier to interpersonal communication. The study is done using a qualitative methodology by explaining the findings. Data collection method of this research is interview, observation, and documents. Interviews and observations conducted to three speakers consisting of one doctor and two patients.The result of this research was explained that the role of the interpersonal communication between doctor and patient will help for recovery of the patients.
\end{abstract}

Keywords: interpersonal communication, message, meaning

\begin{abstract}
Abstrak
Penelitian ini bertujuan untuk meneliti peran komunikasi antarpribadi yang terjadi antara dokter dengan pasien di Klinik Cendana. Teori yang digunakan dalam penelitian ini adalah teori komunikasi, teori komunikasi antarpribadi, efektivitas komunikasi antarpribadi, hambatan komunikasi antarpribadi. Penelitian ini dilakukan dengan metode kualitatif dengan menjelaskan hasil temuan. Metode pengumpulan data dari penelitian ini adalah wawancara, observasi, dan mendokumentasikan. Wawancara dan observasi dilakukan kepada tiga narasumber yang terdiri dari satu dokter dan dua pasien. Hasil dari penelitian ini menjelaskan peran komunikasi antarpribadi dokter dengan pasien dalam penyembuhan pasien di klinik Cendana
\end{abstract}

Kata Kunci: komunikasi antarpribadi, pesan, makna

\section{Pendahuluan}

Manusia adalah makhluk yang tak luput dalam kesehariannya melakukan interaksi. Dalam konteks ini yaitu berkomunikasi, bersosialisasi, dan berkomunikasi. Komunikasi merupakan aspek penting dalam kehidupan, baik dalam membangun relasi, atau menyebarkan informasi. Komunikasi menurut Bernard Berelson dan Gary A. Steiner (Mulyana, 2017 : 68) ialah pengiriman pesan yang berupa emosi, pikiran, kata-kata, informasi, berita, dan lain sebagainya. Dalam berkomunikasi atau menyampaikan pesan terdapat dua bentuk komunikasi yang biasa manusia terapkan dalam kehidupan sehari-hari, bentuk komunikasi tersebut merupakan bagaimana bentuk pesan yang disampaikan yang terdiri dari dua jenis yaitu pesan verbal dan pesan non-verbal. Melalui komunikasi, manusia mampu saling memahami satu sama lain. Komunikasi yang efektif akan terjadi bila dalam penyampaian pesan terjadi timbal balik baik secara verbal maupun non verbal. 
Bagi para dokter, komunikasi tidak luput dari kesehariannya dalam bekerja. Baik dalam melayani pasien maupun memberikan informasi dalam bidang kesehatan. Komunikasi yang dilakukan antara dokter dengan pasien merupakan komunikasi antarpribadi, komunikasi antarpribadi yang terjalin antara dokter dengan pasien merupakan hal utama dalam membangun kepercayaan dan efektifitas atas informasi yang disampaikan. Komunikasi antarpribadi (Mulyana, 2017 : 81) merupakan komunikasi antara dua orang atau lebih yang dapat terjadi baik secara langsung (tatap muka) atau secara tidak langsung dengan tujuan untuk menyampaikan pesan dan menerima timbal balik.

Dalam menjalin komunikasi antara dokter dengan pasien pun harus tercipta sebuah kepercayaan di kedua belah pihak sehingga informasi yang disampaikan oleh dokter terhadap pasien tercapai. Menurut Rusbult dan para kolega (Budyatna, 2001 : 156), para mitra membangunkan rasa kepercayaan antara satu sama lain, maka akan meningkatnya ketergantungan atau saling membutuhkan terhadap satu sama lain. Mereka menjadi semakin akrab, intim. Kepercayaan merupakan hal terpenting dalam terjalinnya komunikasi antarpribadi.

Dalam pembahasan lain, hubungan antara dokter dengan pasien, di mata pasien merupakan hubungan non-interpersonal. Hubungan non-interpersonal menurut Miller dan Steinberg (Budyatna, 2011:36) merupakan hubungan yang terjalin karena pihak tertentu dapat mengisi kebutuhan pihak lainnya yang sifatnya segera. Seperti pasien mendatangi dokter hanya bila terkena penyakit, dokter mampu mengisi peran dalam menyembuhkan penyakit yang diderita pasien tersebut. Jadi semata-mata pandangan pasien terhadap dokter hanya sebagai dokter yang tugasnya membantu bila keadaan sakit. Bila pasien tersebut tidak dalam keadaan sakit, maka pasien tersebut tidak akan mencari dokter.

Komunikasi antara dokter dengan pasien bisa dikatakan komunikasi sebagai transaksi juga. Dalam hal ini seseorang akan melihat respon langsung lawan bicaranya seperti tertawa, memberi isyarat tangan, dan mengangguk. Sehingga proses penyandian dan proses diam - balik bersifat spontan dan simultan bagi orang yang terlibat dalam komunikasi. Dalam konteks ini, komunikasi bersifat antarpribadi. Seperti saat dokter menjelaskan mengenai penyakit yang diderita oleh pasien, lalu pasien akan mengangguk, atau meraut muka. Sehingga respon nonverbal tersebut langsung diterima oleh dokter, dan ditafsirkan.

Berdasarkan latar belakang permasalahan di atas, penulis akan melakukan penelitian mengenai proses komunikasi antarpribadi yang terjadi antara dokter dengan pasien di Klinik Cendana dengan judul "Komunikasi Antarpribadi Dokter dengan Pasien dalam Membantu Penyembuhan Pasien di Klinik Cendana"

\section{Metode Penelitian}

Penelitian ini dilakukan untuk mengetahui komunikasi anatarpribadi yang terjalin antara dokter dengan pasien dalam membantu penyembuhan pasien di Klinik Cendana. Dalam penelitian ini penulis menggunakan penelitian kualitatif. Bodan dan Tailor (Moleong, 2009 : 4) mendefinisikan metode penelitian kualitatif merupakan cara penelitian yang bertujuan untuk mendapatkan data bersifat detail, lengkap, keseluruhan, dan informasi-informasi mendalam baik dalam tulisan maupun lisan dari pihak sumber atau atau narasumber, penelitian kualititatif ini dapat dilakukan dengan cara observasi juga atau pengamatan baik dari segi perilaku khalayak yang 
dapat diamati sebagai sumber data untuk diteliti. Menurutnya pendekatan ini mengarah kepada latar belakang dari setiap pribadi secara keseluruhan.

Creswell (Herdiansyah, 2010: 8) mendefinisikan penelitian kualitatif sebagai suatu proses ilmiah yang lebih mengarah dalam membaca atau memahami masalahmasalah dalam konteks umum atau sosial yang dialami oleh masyarakat dan menciptakan deskripsi secara menyeluruh dan jelas. Dari deskripsi tersebut dibuat dalam bentuk laporan cara pandang terperinci dari para narasumber informasi serta dilakukan dalam setting yang natural atau alamiah tanpa dibuat-buat.

Sedangkan menurut Sugiono (2011: 13), metode penelitian kualitatitif sebagai cara penelitian yang baru karena kemunculan teori yang belum lama. Teori tersebut dinamakan setelah postivistik yang didasarkan atas pengetahuan mengenai postpositivisme, atau sering disebut sebagai metode penelitian artistik, karena proses penelitiannya yang bersifat seni, dan disebut dengan metode penelitian intepretasi. Disebut demikian karena data yang diperoleh dari penelitian lebih mengarah dengan intepretasi berdasarkan data yang diperoleh di lapangan.

\section{Hasil Temuan dan Diskusi}

\section{a. Komunikasi Antarpribadi antara Dokter dengan Pasien}

Menurut Mulyana (2017 : 81), komunikasi antarpribadi komunikasi antara dua orang atau lebih yang dapat terjadi baik secara langsung (tatap muka) atau secara tidak langsung dengan tujuan untuk menyampaikan pesan dan menerima timbal balik. Di tempat lain, Gary D'Angelo (Edi, 2014 : 5) menjelaskan mengenai efektivitas komunikasi antarpribadi, komunikasi antarpribadi terfokus berdasarkan bagaimana baik buruknya pertukaran informasi dari pihak yang terlibat didalamnya. Para partisipan yang saling berhubungan merupakan pribadi yang berbeda dari yang lain, memiliki firasat dan perasaan dan mampu menampilkan kemampuan dirinya masing - masing. Hal ini ditegaskan kembali oleh Supratiknya (Edi, 2014 : 5) bahwa komunikasi antarpribadi sangat penting dalam dunia ini. Komunikasi interpersonal bukan sekedar terjadi dalam kehidupan saja, tetapi juga terjadi dalam sebuah kelompok organisasi baik itu kelompok kecil atau kelompok besar.

Hubungan antara dokter dengan pasien merupakan hubungan yang saling membutuhkan dan terikat. Bila seseorang sakit maka akan ke klinik dan berobat ke dokter. Dan dalam berobat maupun berkonsultasi pasti melakukan komunikasi antarpribadi. Setiap pesan yang disampaikan oleh dokter ke pasien pasti mempunyai tujuan, begitu juga sebaliknya bagaimana pasien menanggapi atau mampu memahami pesan yang disampaikan oleh dokter. Pesan yang disampaikan baik dokter ke pasien maupun sebaliknya harus tepat agar tidak terjadi kesalah pahaman.

\section{b. Karakteristik Komunikasi Antarpribadi}

Komunikasi antara dokter dengan pasien termasuk komunikasi antarpribadi. Menurut Weaver (Budyatna, 2011 : 15), karakteristik - karakteristik komunikasi antarpribadi sebagai berikut:

\section{Melibatkan paling sedikit dua orang}

Komunikasi antarpribadi melibatkan paling sedikit dua orang menurut Weaver, komunikasi antarpribadi yang terjadi dapat terjadi dengan peran paling sedikit dua orang maupun terhadap beberapa orang atau kelompok kecil. Komunikasi yang terjalin bersifat intim sehingga agar tetap terjalinnya efektifitas komunikasi 
antarpribadi tidak mampu menyampaikan pesan dalam skala besar atau kelompok besar.

\section{Adanya umpan balik atau feedback}

Komunikasi antarpribadi melibatkan umpan balik. Umpan balik merupakan tindakan atau sikap yang diberikan dari penerima pesan atas pesan atau informasi yang disampaikan oleh komunikator. Umpan balik yang baik dapat terjadi bila komunikan mampu memahami pesan secara baik yang disampaikan oleh komunikator.

\section{Tidak harus tatap muka}

Dalam komunikasi antarpribadi, pesan yang disampaikan tidak harus tatap muka. Dalam hal ini komunikasi yang terjalin dapat terjadi dengan menggunakan media - media seperti : telepon, pesan online, dan lain sebagainya.

\section{Tidak harus bertujuan}

Terkadang komunikasi antarpribadi terbangun atas dasar ketidak sengajaan dari pihak komunikator terhadap komunikan. Tanpa tujuan yang sifatnya abstrak dalam berkomunikasi.

\section{Menghasilkan beberapa pengaruh}

Komunikasi antarpribadi yang terjalin dapat memberikan pengaruh baik dari pihak koununikator maupun komunikan. Pesan yang disampaikan dapat memiliki tujuan yang biasanya bermanfaat, sehingga memberikan pengaruh terhadap responden maupun sebaliknya.

\section{Tidak harus menggunakan kata - kata}

Dalam hal ini menjelaskan mengenai bahwa komunikasi antarpribadi dapat terjalin secara non-verbal, seperti : kedipan mata, senyuman, dan bahasa non-verbal lainnya. Pesan non-verbal yang disampaikan memiliki makna.

\section{Dipengaruhi oleh konteks}

Menurut Verderber (Budyatna, 2011 : 14), konteks merupakan tempat di mana pertemuan informasi-informasi atau pesan-pesan yang telah disampaikan dan menerima timbal balik dari pihak-pihak yang terlibat. Hal ini melibatkan harapanharapan dari pihak-pihak tersebut dalam memahami makna pesan, selanjutnya. Konteks meliputi :

1) Jasmaniah, konteks jasmaniah atau fisik terdiri dari tempat, keadaan lingkungan seperti : cuaca, suhu udara, dan tingkat kegaduhan, jarak antara komunikator, setting tempat, dan mengenai waktu.

2) Sosial, konteks sosial merupakan bentuk hubungan yang mungkin sudah ada di antara para partisipan.

3) Sejarah, konteks sejarah merupakan latar belakang para partisipan komunikasi yang sedang terjalin, baik dari peristiwa yang pernah terjadi lampau ataupun latar belakang pribadi partisipan tersebut.

4) Psikologis, konteks psikologis meliputi suasana hati dan perasaan di mana setiap orang membawakannya kepada pertemuan antarpribadi.

5) Keadaan kultural. Menurut Samover dan Porter (Budyatna, 2011 : 16). Konteks budaya atau keyakinan, strata atau tingkatan, pemikiran, pemahaman, pandangan mengenai waktu dan peran partisipan.

\section{Dipengaruhi oleh kegaduhan}

Kegaduhan yang terjadi memberikan stimulus terhadap orang yang menerima dampak dari hal tersebut. Kegaduhan tersebut terdiri dari : 
1) Kegaduhan eksternal, merupakan kegaduhan yang biasa terjadi dari faktor penglihatan, suara atau kebisingan dan berbagai rangsangan lainnya dalam suatu lingkungan.

2) Kegaduhan internal, berupa pikiran - pikiran dan perasaan - perasaan yang bersaing untuk mendapatkan perhatian dan mengganggu proses komunikasi.

3) Kegaduhan semantik, berupa gangguan yang ditimbulkan oleh lambang lambang tertentu yang menjauhkan perhatian kita dari pesang yang utama.

\section{c. Hambatan Komunikasi Antarpribadi}

Dalam komunikasi antarpribadi, terdapat hambatan-hambatan yang terjadi. Menurut Eisenberg (Liliweri, 2015: 459) hambatan komunikasi dibagi menjadi empat jenis, yaitu hambatan proses, fisik, semantik dan psikologis.

Hambatan komunikasi yang terjadi antara dokter dengan pasien dapat menghambat kesembuhan pasien. Jika hambatan komunikasi tersebut tidak diatasi, maka pasien tidak memahami pesan dan saran yang diberikan dokter terhadap pasien tersebut. Pesan dan saran dari dokter bertujuan untuk kesembuhan pasien tersebut. Tapi bila pasien tidak memahami, maka pasien tidak akan mengetahui yang harus dilakukan. Seperti dalam hal menjaga kesehatan setelah sudah sembuh, ataupun mengenai pemakaian obat yang telah dianjurkan oleh dokter.

\section{d. Efektifitas Komunikasi Antarpribadi}

Komunikasi antarpribadi yang terjalin antara dokter dengan pasien haruslah efektif, agar tidak terjadi kesalahpahaman dan mampu mendapat informasi sejelas mungkin. Sehingga dokter pun mampu mengetahui penyakit atau keluhan pasien secara keseluruhan, begitu juga sebaliknya pasien mampu mendengarkan pesan atau informasi yang disampaikan oleh dokter dengan jelas. Ada lima aspek efektifitas komunikasi antarpribadi. Menurut De Vito (1997 : 285-291), komunikasi interpersonal berlangsung dengan efektif, maka ada beberapa aspek yang harus diperhatikan oleh para pelaku komunikasi interpersonal, ialah:

\section{Keterbukaan (openness)}

Keterbukaan adalah kemauan dari partisipan membuka diri dalam berkomunikasi atau berinteraksi dengan lawan bicaranya. Kualitas komunkasi ditentukan dari seberapa partisipan saling terbuka satu sama lain. Sifat keterbukaan yang dibangun bertujuan agar komunikasi antarpribadi yang terjalin efektif, dan pesan makna yang disampaikan mampu dipahami dengan baik, timbal balik dari pesan yang disampaikan pun juga sesuai harapan.

\section{Empati (emphaty)}

Empati merupakan kemampuan manusia untuk dapat merasakan berbagai hal dari orang lain. Hal ini merupakan salah satu cara agar dapat melakukan pemahaman terhadap pihak lain. Empati dapat terjadi atau diterapkan secara verbal atau nonverbal.

\section{Sikap mendukung (supportive)}

Sikap saling mendukung antar partisipan (komunikator dan komunikan) akan menciptakan situasi komunikasi antarpribadi yang efektif. Komunikasi antarpribadi dapat terjalin efektif bila kedua belah pihak tidak menumbuhkan sikap defensive. Hal tersebut sangat menghambat efektifitas komunikasi antarpribadi. sikap mendukung dalam hal ini, yaitu dengan saling menghargai lawan bicara, tanpa menyelak, menghargai dan memberikan timbal balik pesan sesuai dengan konteks yang sedang dibahas. 


\section{Sikap positif}

Dalam komunikasi interpersonal, setiap individu memiliki kemampuan dalam memandang dirinya sendiri secara positif dan orang lain. Sikap positif tak luput dari upaya mendorong, menerima keberadaan serta pentingnya memahami pihak lain yang berkaitan.

\section{Kesetaraan (equality)}

Komunikasi antarpribadi efektif apabila terjalin kesetaraan di antara para partisipan. Sesama partisipan saling menghargai satu sama lain dalam komunikasi, memunculkan sifat keseimbangan antar individu yang bertujuan untuk membangun rasa kenyamanan dan kesamaan antar partisipan dalam berkomunikasi.

\section{Simpulan}

Komunikasi antarpribadi yang terjalin antara dokter dengan pasien akan berjalan dengan baik, bila dari pihak dokter dan pasien saling memahami, saling terbuka, saling peduli. Komunikasi yang terjalin antara dokter dengan pasien akan mempengaruhi kinerja di lingkungan tersebut, dan mampu menarik masyarakat untuk berobat ataupun berkonsultasi mengenai kesehatan di klinik.

Dengan keberagaman masyarakat tidak menjadi hambatan bagi dokter melakukan komunikasi terhadap pasien yang ingin berobat. Perbedaan latar belakang pun juga tidak menjadi hambatan, karena para dokter selalu mengutamakan pasien dengan cara menghargai dan memahami keinginan pasien tersebut terlebih dahulu.

\section{Ucapan Terima Kasih}

Peneliti mengucapkan terima kasih kepada narasumber yang telah memberikan kesempatan dan waktu dalam konteks berbagi informasi secara mendalam. Peneliti berterima kasih yang tertuju pada para dosen yang sudah membina, membimbing dan mengarahkan dalam penyusunan skripsi. Peneliti juga mengucapkan terima kasih terhadap teman-teman kampus yang telah bersedia membantu, menemani dalam penyusunan penelitian ini.

\section{Daftar Pustaka}

Budyatna, Muhamad (2011). Teori Komunikasi Antarpribadi. Jakarta : Kencana Prenada Media Group.

Devito, Joseph A. (2011). Komunikasi Antar Manusia. Pamulang-Tangerang Selatan : Karisma Publishing Group

Harapan, Edi. (2014). Komunikasi Antarpribadi. Jakarta: PT Raja Grafindo Persada. Herdiansyah, Haris. (2010). Metodologi Penelitian Kuantitatif. Jakarta: Salemba Humanika.

Moleong, Lexy J. (2009). Metode Penelitian Kualitatif. Bandung : Remaja Rosdakarya.

Mulyana, Deddy. (2014). Ilmu Komunikasi: Suatu Pengantar. Cetakan ke 18. Bandung: PT. Remaja Rosdakarya.

Sugiyono. (2011). Metode Penelitian Kuantitatif, Kualitatif dan R\&D. Bandung: Afabeta 